\title{
Diversity of Parent Magmas of Higashi-Izu Monogenetic Volcano Group
}

\author{
Susumu Umino, ${ }^{*}$ Megumi Kato, and Masato Koyama \\ Institute of Geosciences, Faculty of Science, Shizuoka University, \\ Shizuoka 422, Japan
}

\begin{abstract}
Systematic correlations are recognized between spinel and olivine in basalts and andesites, and the whole rock compositions of the Higashi-Izu monogenetic volcano group (HMVG), Izu Peninsula. Low-Cr spinel coexists with low-Ni, high-Mg olivine, both of which have crystallized from type $\mathrm{A}$ magmas with low $\mathrm{Fe} / \mathrm{Mg}$ and $\mathrm{Ni} / \mathrm{Mg}$ ratios. High-Cr spinel and high-Ni olivine have crystallized from type B magmas higher in $\mathrm{SiO}_{2}$ content, $\mathrm{Fe} / \mathrm{Mg}$ and $\mathrm{Ni} / \mathrm{Mg}$ ratios than the former. Mixing of type $\mathrm{A}$ and $\mathrm{B}$ magmas would yield transitional magma type $\mathrm{AB}$. Type $\mathrm{C}$ magmas have crystallized extremely high-Cr spinel and nickeliferous olivine. The activity of type B magmas has continued since the earliest stages of the volcanic history of the HMVG, but is restricted in the northeast of the volcanic region. On the contrary, type A magmas have erupted since the last 22,000 years and are mainly concentrated in the southwest. Type $\mathrm{AB}$ magmas occur in the transitional area between type A and B magmas. The secular and spatial variations in mineral and whole rock chemistry suggest that type B magmas were produced by assimilation of tonalitic upper crust.
\end{abstract}

\section{Introduction}

Higashi-Izu monogenetic volcano group (HMVG) comprises 79 vents sporadically distributed in the northeast of Izu Peninsula. The only historic eruption of 1989 on the seafloor off the coast of Ito has shown that this volcano group is still active. Recent study on this volcano group (Koyama et al., 1990; Koyama and Umino, 1991) has suggested that it has erupted since 100 thousand years B. P., much earlier than it was thought by the previous workers (Aramaki and Hamuro, 1977; Hamuro, 1978). Total volume of erupted materials amounts to $2.5 \mathrm{~km}^{3}$, one sixth of which are occupied by lava flows and pyroclastic materials ejected from Omuroyama. On the seafloor between the eastern coast of Izu Peninsula and Izu-Oshima are more than 50 seamounts, most of which are considered to be submarine volcanoes (Yuasa and Honza, 1976; Hamuro et al., 1980, 1983). The southern half of them are mostly composed of low-alkali tholeiite series rocks very much similar to those of Izu-Oshima Volcano. The northern half of them consist of high-alkali tholeiitic basalts and andesites chemically and petrograph-

Received August 27, 1990; Accepted January 11, 1991

* To whom correspondence should be addressed. 
ically similar to those of the subareal monogenetic volcanoes. Therefore, we include the high-alkali tholeiitic submarine volcanoes among the HMVG. Thus, the HMVG comprises more than 90 volcanoes and is distributed in the areas with dimensions of $35 \mathrm{~km} \mathrm{E-W}$ and $25 \mathrm{~km} \mathrm{~N}$-S. Independent group of monogenetic volcanoes is empirically known from intracontinental areas such as the rift system of East Africa, Victoria in southeastern Australia and Eifel in western Germany, and from back arc side of southwest Japan. The HMGV is the only known example which is located on the volcanic front along the arc-trench system. The tectonics of the HMVG is outside the scope of this paper and is discussed in detail by Koyama and Umino (1991).

Whole rock composition of the volcanic ejecta ranges in $\mathrm{SiO}_{2}$ content from 49 to $60 \mathrm{wt} \%$ and from 68 to $73 \mathrm{wt} \%$ (Hamuro, 1985; Miyajima et al., 1985). Andesites $\left(\mathrm{SiO}_{2}>53 \mathrm{wt} \%\right)$ volumetrically predominate, followed by rhyolites and dacites. The origin of felsic magmas is most explicable by remelting of granitic crust by basaltic magmas (Hamuro, 1985). The andesites are interpreted to have been formed by assimilation of granitic materials in mafic magmas. Kuno (1954) and Hamuro (1985) have considered the contaminated mafic magmas to be basaltic, while Miyajima et al. (1985) have suggested that the host magma would have a wide range of composition from basalt to andesite. However, the most voluminous andesite lavas from Omuroyama have forsteritic olivine phenocrysts $\left(F_{0}<85\right)$ which are identical to those in basalts. Thus, the contaminated magmas seem to be mostly basaltic as proposed by Hamuro (1985). The parent magmas for these basalts are of two types: one has lower $\mathrm{Ba} / \mathrm{Ca}$ (Hirano et al., 1982) and yields basalt I of Hamuro (1985), and the other has higher $\mathrm{Ba} / \mathrm{Ca}$ and yields basalt II.

The previous studies have concentrated on the interaction of basaltic magmas and crustal materials, and none of them have considered the significance of diversity of parent magmas, hence the nature of the source mantle which produced the heterogeneity. For elucidation of the diversity of parent magmas by comparing bulk compositions of the volcanic rocks, the major obstacle is the difficulty in eliminating the effect of contamination and assimilation. Another problem is that even the most primitive basalt among the HMVG has been differentiated and does not retain the primary magma composition. In order to avoid the first obstacle, we focus on olivine and spinel phenocrysts in basalts and andesites, which would correlate with melt compositions of the magmas prior to crustal assimilation. This paper presents detailed analyses of olivine and spinel included in mafic lavas of the HMVG and discusses the diversification of the parent magmas through time and space.

\section{Sample Description}

Twenty-three samples were prepared for an EPMA analysis. Sample locations are shown in Fig. 1. All the analyzed samples are lava flows except Teisi Knoll and Marunoyama. The sample of Teisi Knoll is a lithic clast of basalt collected from the vent. The sample from Marunoyama is a scoriaceous block constituting the cinder cone of Marunoyama. Petrography of the samples is summarized in Table 1. Olivine phenocryst with tiny spinel inclusions is common in all samples except that from Joboshi, which carries only a small amount of olivine microphenocrysts. Olivine occurs as either 


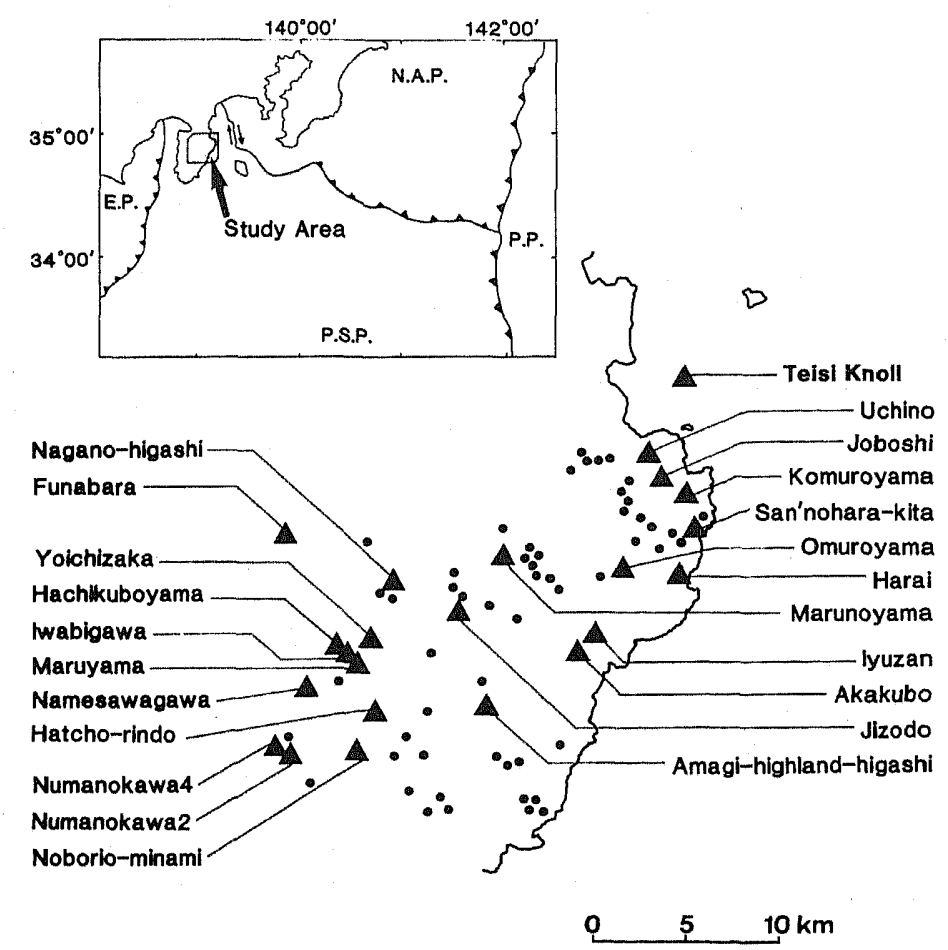

Fig. 1. Distribution of the vents of the Higashi-Izu monogenetic volcano group (HMVG). Analyzed sample locations are shown by large triangles with names of the volcanoes. N. A. P., North American Plate; P. P, Pacific plate; P. S. P., Philippine Sea plate; E. P., Eurasia plate.

euhedral, skeletal phenocrysts and microphenocrysts or crystal clots with plagioclase and augite. A trace amount of pale brown spinel or titanomagnetite is invariably included in olivine and rarely in augite phenocrysts and microphenocrysts. They occur as tiny octahedra 10 to $50 \mu \mathrm{m}$ in diameter. Plagioclase is less common than olivine as a phenocryst phase, but is most abundant in augite-bearing samples. Hypersthene is found in some differentiated lavas as small, elongate phenocrysts. Xenocrysts are included in almost all samples. Xenocrystic plagioclase is identified by a mixture of calcic plagioclase and brown glass inclusions, giving a dusty, patchy appearance. A corroded, clear core of sodic plagioclase is occasionally found embedded in the dusty plagioclase. Quartz xenocrysts are corroded and surrounded by brown glass with a rim of augite crystals. A prismatic aggregate of tiny elongate pyroxenes and fine magnetite is probably decomposed hornblende. The most plausible origin of these xenocrysts are tonalitic upper crust beneath the Izu Peninsula (Kuno, 1954; Hamuro, 1985; Miyajima et al., 1985). 


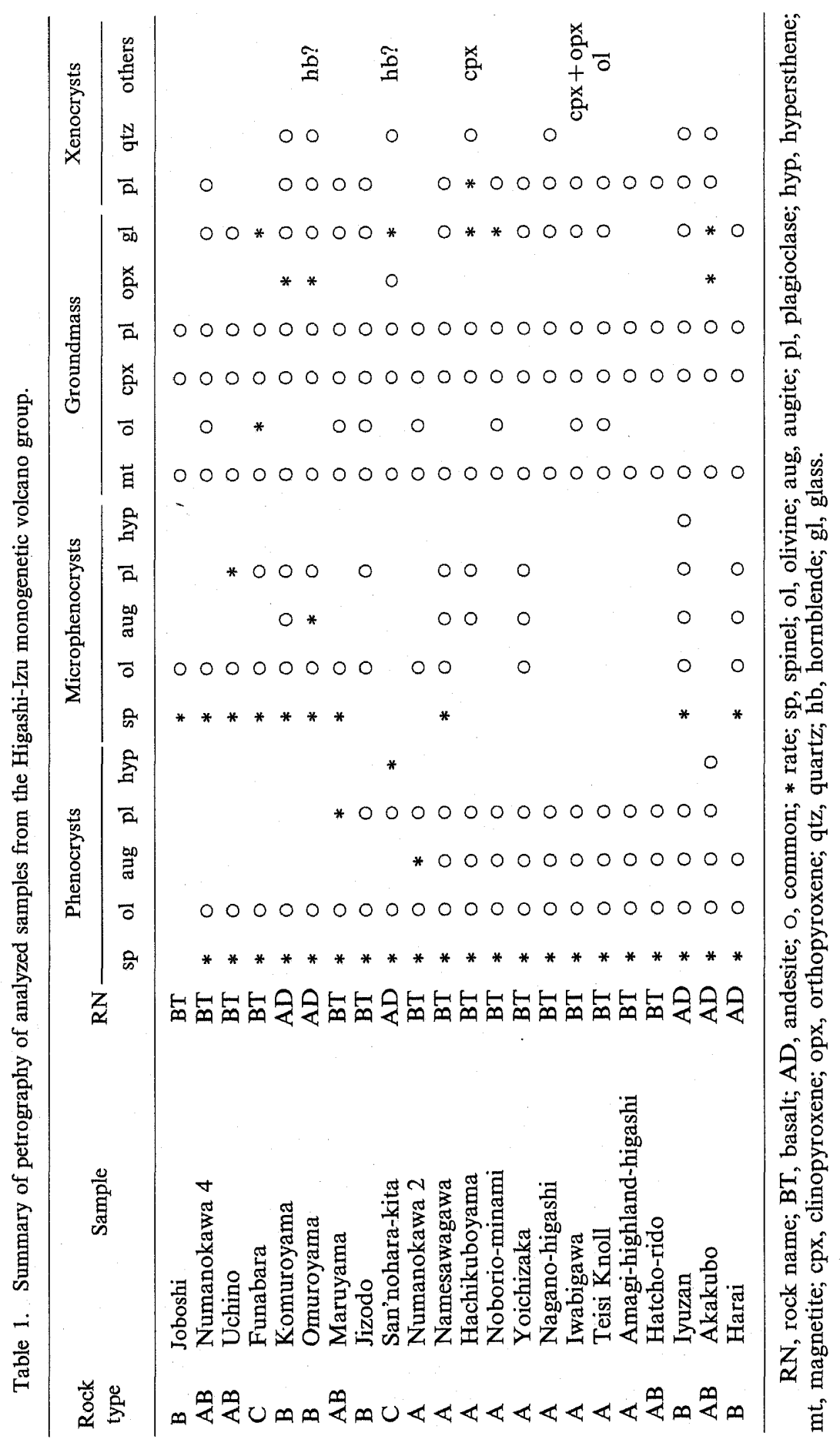

J. Phys. Earth 


\section{Mineral Chemistry}

Olivine and spinel compositions were determined by the JEOL JCXA-733 electron-probe microanalyzer of the Institute of Geosciences, Shizuoka University. The accelerating voltage was $15 \mathrm{kV}$ and the specimen current was $12 \pm 0.1 \mathrm{nA}$. The corrections were made according to the method of Bence and Albee (1968) using the alpha factors of Nakamura and Kushiro (1970). For analyses of trace elements in olivine, five 20-s counts were done on each spot for $\mathrm{Mn}$ and $\mathrm{Ni}$, and three 10-s counts were for $\mathrm{Fe}$ and $\mathrm{Mg}$. The standard errors of $\mathrm{MnO}$ and $\mathrm{NiO}$ are less than $0.02 \mathrm{wt} \%$. For analyses of coexisting olivine and spinel, counting times for $\mathrm{Mg}, \mathrm{Fe}, \mathrm{Al}$, and $\mathrm{Cr}$ were two $10 \mathrm{~s}$.

\section{$3.1 \mathrm{NiO}$ vs. Fo variation of olivine}

Figure 2(a) shows $\mathrm{MnO}$ vs. Fo contents in olivine phenocrysts and microphenocrysts. Each spot represents an average composition of 4 points in the core of a single olivine crystal.

Most of the samples exhibit similar linear trends on the $\mathrm{MnO}$ vs. Fo variation diagram, increasing in $\mathrm{MnO}$ from $0.2 \mathrm{wt} \%$ at $\mathrm{Fo}_{86}$ up to $0.5 \mathrm{wt} \%$ at $\mathrm{Fo}_{66}$. Only olivine in the lava of Uchino shows a curved variation slightly concave upwards, but the $\mathrm{MnO}$ concentration at a given Fo content is almost identical to that of other samples.

$\mathrm{NiO}$ vs. Fo variations are shown in Fig. 2(b)-(d). The NiO content generally decreases together with the Fo content, suggesting $\mathrm{Ni}$ depletion in residual melts as crystallization of olivine proceeds. The most nickeliferous olivine contains $0.33 \mathrm{wt} \%$ $\mathrm{NiO}$ at $\mathrm{Fo}_{86}$, which occurs in the lava of Numanokawa 4. Maruyama sample has the most forsteritic olivine of $\mathrm{Fo}_{87}$, but its $\mathrm{NiO}$ content is as low as $0.25 \mathrm{wt} \%$. In contrast with $\mathrm{MnO}$, the $\mathrm{NiO}$ variation against Fo is highly variable. The patterns on the NiO-Fo variation diagrams are divided into four types. These types of variation patterns are schematically shown in Fig. 3. The rock types are defined according to the NiO vs. Fo variation patterns, and are listed in Table 1. Olivines of type A samples are higher in Fo contents than olivines of any other rock types with $\mathrm{NiO}$ content higher than $0.15 \mathrm{wt} \%$, or are lower in $\mathrm{NiO}$ content than the others at Fo less than 83, and are plotted on the left side and bottom of the diagram. Most of the analyzed samples are of rock type A. One type A sample, Teisi Knoll, displays an inflection point on the $\mathrm{NiO}$ vs. Fo variation curve. The olivine rapidly decreases in $\mathrm{NiO}$ until $\mathrm{Fo}_{83}$, then the decrease rate in $\mathrm{NiO}$ becomes less at lower $\mathrm{Fo}$ contents. Olivines of type B samples display sharp decrease in $\mathrm{NiO}$ with decreasing $\mathrm{Fo}$, indicating fractional crystallization trends. The samples of this type are Joboshi, Jizodo, Komuroyama, Omuroyama, Iyuzan, and Harai. The NiO concentration of type $\mathrm{C}$ olivines also decreases monotonously as that of type $\mathrm{B}$, but the slope is very gentle. This rock type, Funabara and San'nohara-kita, has olivines with the highest $\mathrm{NiO}$ content at a given $\mathrm{Fo}$ among all the samples of the HMVG. Rock type $\mathrm{AB}$ carries olivines reducing in $\mathrm{NiO}$ monotonously with decreasing Fo, but as gradual as those of type $\mathrm{C}$ samples. The olivines of this type range in $\mathrm{NiO}$ content from approximately $0.20 \mathrm{wt} \%$ at $\mathrm{Fo}_{84}$ to $0.10 \mathrm{wt} \%$ at $\mathrm{Fo}_{70}$, which overlaps those of type $\mathrm{B}$ samples and is between those of type $\mathrm{A}$ and $\mathrm{C}$ samples.

Co-crystallization of olivine and other phases containing $\mathrm{Ni}, \mathrm{Fe}$, and $\mathrm{Mg}$ will affect the $\mathrm{NiO}$ and Fo contents in olivine. For example, removal of Ni-bearing phases such

Vol. 39, No. 1, 1991 


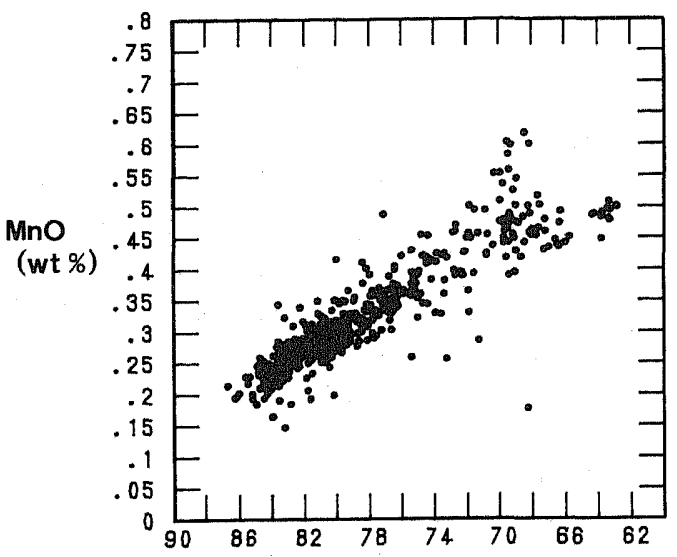

Fo

(a)

Type A
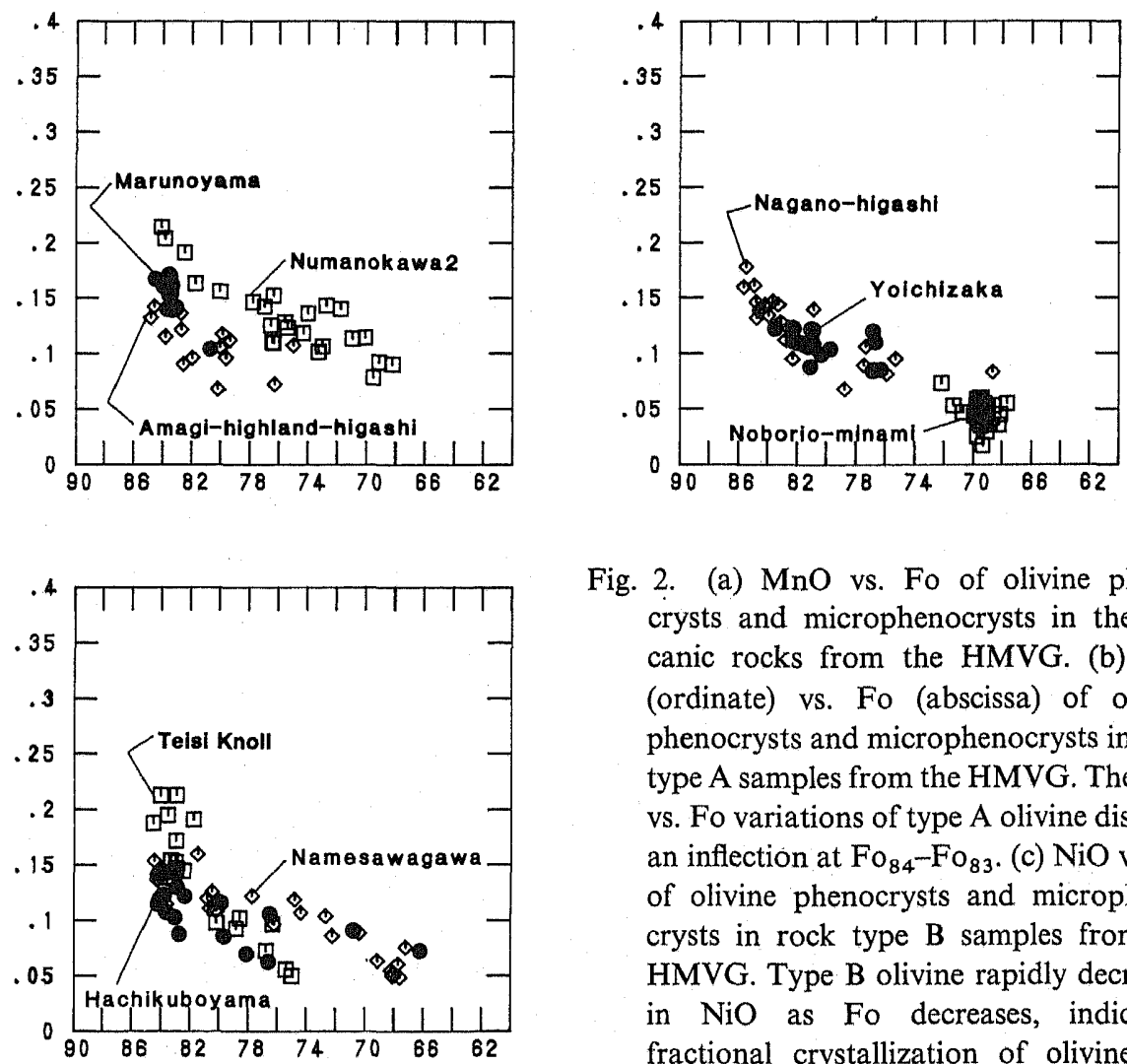

Fig. 2. (a) $\mathrm{MnO}$ vs. Fo of olivine phenocrysts and microphenocrysts in the volcanic rocks from the HMVG. (b) NiO (ordinate) vs. Fo (abscissa) of olivine phenocrysts and microphenocrysts in rock type A samples from the HMVG. The NiO vs. Fo variations of type $A$ olivine displays an inflection at $\mathrm{Fo}_{84}-\mathrm{Fo}_{83}$. (c) $\mathrm{NiO}$ vs. Fo of olivine phenocrysts and microphenocrysts in rock type $B$ samples from the HMVG. Type B olivine rapidly decreases in $\mathrm{NiO}$ as $\mathrm{Fo}$ decreases, indicating fractional crystallization of olivine. (d)

(b) NiO vs. Fo of olivine phenocrysts and 


\section{Type B}
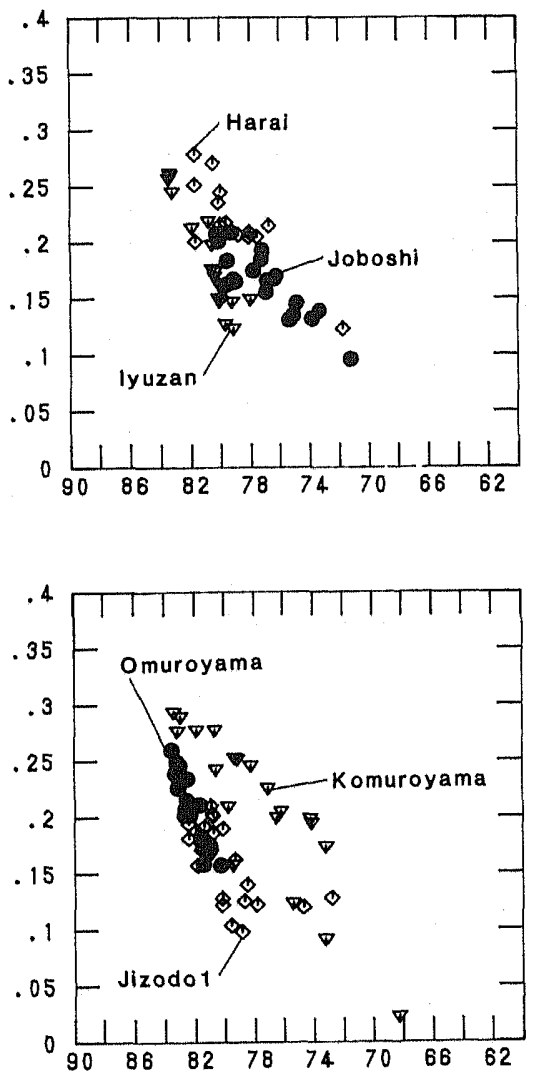

(c)
Type C

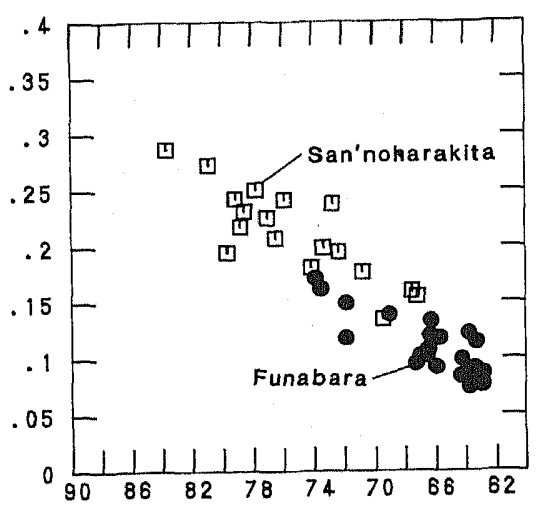

(d)

\section{Type AB}

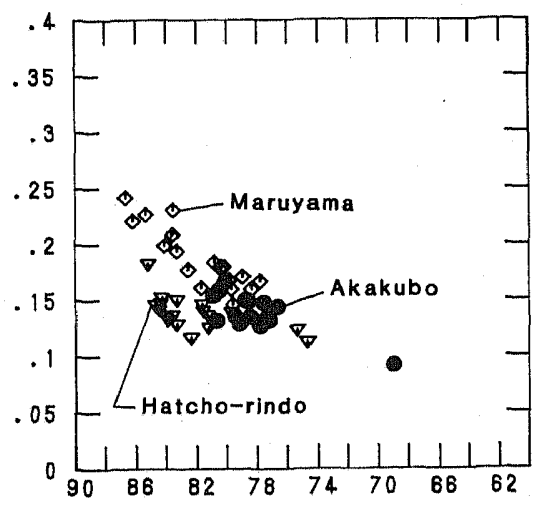

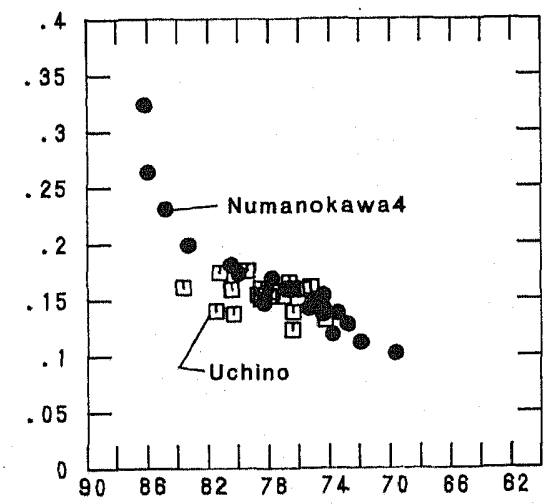

(e) microphenocrysts in rock type $C$ samples from the HMVG. Olivines in type $\mathrm{C}$ samples are up to $\mathrm{Fo}_{84}$ and $\mathrm{NiO}$ contents of $0.3 \mathrm{wt} \%$, which is similar to the most forsteritic olivines in type B samples, and gradually or slightly reduce $\mathrm{NiO}$ with decreasing Fo content. (e) $\mathrm{NiO}$ vs. Fo of olivine phenocrysts and microphenocrysts in rock Type $A B$ samples. Olivines in type $\mathrm{AB}$ samples exhibit gradual decrease in $\mathrm{NiO}$ as those in type $\mathrm{C}$, but are depleted in Ni compared to the latter with a similar Fo content.

Vol. 39, No. 1, 1991 


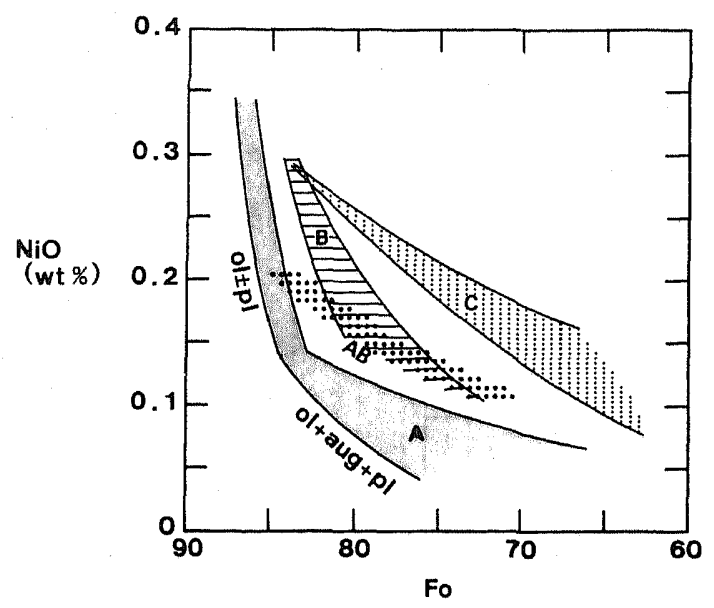

Fig. 3. Schematic diagram showing the variations in $\mathrm{NiO}$ vs. Fo of olivine in type $\mathrm{A}, \mathrm{B}, \mathrm{C}$, and $\mathrm{AB}$ samples. Olivine crystallizing from type A magmas rapidly decrease in $\mathrm{NiO}$ with reducing $\mathrm{Fo}$ at first, then the decreasing rate of $\mathrm{NiO}$ becomes lower as augite starts crystallization. Olivine in the samples of type $\mathrm{B}$ is less forsteritic than that of type $\mathrm{A}$, but decreases $\mathrm{NiO}$ as soon as type $\mathrm{A}$ olivine. The variations of both type A and type B are produced by fractional crystallization. Type $\mathrm{C}$ olivine is higher in $\mathrm{NiO}$ than other types, and slowly reduces $\mathrm{Ni}$ as $\mathrm{Fo}$ content decreases. Type $\mathrm{AB}$ olivine has intermediate $\mathrm{NiO}$ between type $\mathrm{A}$ and $\mathrm{C}$ olivines, and the decreasing rate of $\mathrm{NiO}$ is as small as that of type $C$. This variation would be formed by the mixing of type $A$ and $B$ magmas.

as sulfide and spinel will cause rapid depletion of $\mathrm{Ni}$ in the residual melt, resulting in low- $\mathrm{Ni}$, high-Fo olivine. On the contrary, crystallization of $\mathrm{Ni}$-free ferromagnesian minerals such as pyroxenes will push the residual melt towards $\mathrm{Fe}$-enrichment, but does not reduce $\mathrm{Ni}$ concentration in the melt. So, $\mathrm{Ni}$ concentration in olivine at a given Fo content will be higher if pyroxene crystallizes together with olivine compared to the case in which olivine alone crystallizes. The variation curves of olivines in rock type B samples on the NiO vs. Fo diagram are those expected for fractional crystallization paths of olivine. The sample of Joboshi carries olivine with spinel inclusions as the only microphenocryst and no other phase is present as a phenocryst or a microphenocryst. Because Joboshi olivine displays chemical variations expected for fractional crystallization, co-crystallization of small amount of spinel would not have affected the $\mathrm{Ni}$ concentration in olivine. Another type B samples, Omuroyama and Jizodo, have plagioclase microphenocrysts or phenocrysts, but these phases do not affect the Ni-Fo relations of olivine. The sample of Iyuzan contains augite phenocrysts, but the compositional variation of olivine resembles that expected for the fractional crystallization of olivine alone. The olivine and augite phenocrysts occasionally occur as crystal clots together with plagioclase, suggesting concurrent crystallization. The core composition of augite ranges in $\mathrm{Mg} \#(100 \times \mathrm{Mg} /(\mathrm{Mg}+\mathrm{Fe}))$ from 84 to 70 , while that 
of olivine has Fo content from 84 to 78 . The Fe-Mg partitioning data between naturally occurring olivine and augite phenocrysts in volcanic rocks suggests that the olivine might have crystallized together with the Mg-rich augite (Sakuyama, 1981), although the NiO-Fo variation of olivine is that expected for the fractional crystallization of olivine alone. One of the possibilities to explain this discrepancy is the change in $\mathrm{Ni}-\mathrm{Mg}$ exchange partition coefficient $(\mathrm{Kd}(\mathrm{Ni}-\mathrm{Mg}))$ between olivine and a magma. The $\mathrm{Kd}(\mathrm{Ni}-\mathrm{Mg})$ value becomes larger for andesitic magmas than for basaltic magmas. Bulk $\mathrm{SiO}_{2}$ content of the Iyuzan lava is $57.8 \mathrm{wt} \%$ on an anhydrous basis. The $\mathrm{NiO}$ and $\mathrm{Fo}$ relations of olivine of the Iyuzan lava could be explained by a higher $\mathrm{Kd}(\mathrm{Ni}-\mathrm{Mg})$ for the Iyuzan magma than that for the other samples. However, on the basis of Fe-Mg partitioning (Roeder and Emslie, 1970), the olivine which could be in equilibrium with the bulk composition of the Iyuzan lava is $\mathrm{Fo}_{76.8}$ at most, whereas the modal olivine in the Iyuzan lava has Fo content up to 84. The olivine phenocrysts in the Iyuzan lava are too magnesian to be equilibrated with the bulk composition. Therefore, the apparent high $\mathrm{Kd}(\mathrm{Ni}-\mathrm{Mg})$ is due to the disequilibrium existence of high- $\mathrm{Ni}$, high- $\mathrm{Mg}$ olivine in the andesitic bulk composition. As is proposed by several workers (e.g., Hamuro, 1985), some of the andesitic magmas of the HMVG were produced through the assimilation of granitic materials by basaltic magmas. It is plausible that the Iyuzan magma may be one of such magmas; i.e., the contaminated basaltic magmas which have already crystallized the olivine, $\mathrm{Mg}$-rich augite and plagioclase phenocrysts before assimilating the granitic crust. Consequently, the high $\mathrm{Kd}(\mathrm{Ni}-\mathrm{Mg})$ is not expected for the crystallization of olivine in the Iyuzan magma. The NiO-Fo relationships of olivine in the Iyuzan lava is not explicable so far.

All Type A samples have a significant amount of augite and plagioclase phenocrysts as well as olivine. These phenocrysts frequently occur as crystal clots, suggesting concurrent crystallization. Thus, the gradual decrease in $\mathrm{NiO}$ of olivine at Fo less than 83 could be explained by the co-crystallization of augite phenocrysts. The olivine phenocrysts in Teisi Knoll exhibit an inflection at $\mathrm{Fo}_{83}$ on the NiO vs. Fo variation. This sample has augite and plagioclase as well as olivine. NiO content of the olivine decreases rapidly from $\mathrm{Fo}_{84}$ to $\mathrm{Fo}_{83}$, then decreases slowly down to $\mathrm{Fo}_{74}$, whereas $\mathrm{Mg}$ \# of the coexisting augite is only 83 at most. This suggests that olivine has crystallized prior to augite. As in other type A samples, the change of the rate of $\mathrm{Ni}$ depletion is, therefore, due to the co-crystallization of augite. At first, only olivine and spinel crystallized from the magma of Teisi Knoll as liquidus phases, joined by augite at $\mathrm{Fo}_{83}$. The olivine phenocrysts followed the fractional crystallization path on the NiO-Fo variation diagram until they reached $\mathrm{Fo}_{83}$, then followed the co-crystallization path with augite.

The olivine phenocrysts of San'nohara-kita (type C) have a similar NiO-Fo relationship to type $\mathrm{AB}$ samples, but are most enriched in NiO. Except for olivine, the sample of San'nohara-kita has phenocrysts of plagioclase, and rare spinel and hypersthene. The amount of spinel and hypersthene is so small that crystallization of these phases would not affect the $\mathrm{NiO}$ content in the co-crystallizing olivine. Because there is no evidence of magma mixing, the gradual decrease in $\mathrm{Ni}$ would indicate equilibrium crystallization path. Another possibility is the different $\mathrm{Kd}(\mathrm{Ni}-\mathrm{Mg})$ between olivine and the magma. However, any fact which suggests different $\mathrm{Kd}(\mathrm{Ni}-\mathrm{Mg})$ has 
not been identified yet.

Type AB samples do not always contain augite phenocrysts, although their olivine exhibits similarly gradual decrease in $\mathrm{NiO}$ as type A samples. The sample of Uchino has olivine with tiny spinel inclusions as the only phenocryst. The olivine ranges in Fo content from 84 to 74 , but is nearly constant in NiO within $0.15 \pm 0.025$. An olivine phenocryst in the Uchino sample has a normally zoned forsteritic core with reversely zoned rim. $\mathrm{NiO}$ concentration of the olivine remains nearly constant in the core, but abruptly increases near the rim and then decreases towards the rim. The increase in Fo content could be due to oxidation of the magma just prior to the eruption. However, the increase in $\mathrm{NiO}$ near the rim cannot be explained by the change in $\mathrm{Fe}^{3+} / \mathrm{Fe}^{2+}$ ratio of the magma. In order to explain the reverse zoning in both $\mathrm{NiO}$ and $\mathrm{Fo}$, mixing of two magmas carrying Fo-rich and Fo-poor olivines appears to be most plausible. One of the candidates for the magnesian end member of the mixed two magmas is such a magma as Teisi Knoll. The other end member should have olivine with higher NiO than that of Teisi Knoll. The likely candidates for such magmas are of type B. Both magmas should have fractionated forsteritic olivines that have already crystallized before the mixing. Then type B magmas with Fo-poor but nickeliferous olivine have mixed with the magmas such as Teisi Knoll with Fo-rich but similarly nickeliferous olivine before crystallization of augite.

Numanokawa 4 (type $\mathrm{AB}$ ), also displays an inflection on the $\mathrm{NiO}$ vs. Fo variation diagram as Teisi Knoll (type A), but the inflection point is shifted towards higher Fo and $\mathrm{NiO}$ than that of the latter. It should be noted that the sample of Numanokawa 4 has only olivine and spinel as phenocrystic phases, and lacks augite. The variation of $\mathrm{NiO}$ vs. Fo fits those of type $\mathrm{AB}$ olivines, which are formed through magma mixing. As type $\mathrm{AB}$ olivines, the mixing of two magmas carrying Fo-rich and Fo-poor olivine phenocrysts might have produced olivine in Numanokawa 4 . The olivine crystals in Numanokawa 4 are bi-modal in both Fo content and size of the crystals. The larger phenocrysts are highly forsteritic with a constant core composition of $\mathrm{Fo}_{86}$ and the smaller microphenocrysts are less forsteritic with Fo content of 67-73. These microphenocrysts are, however, normally zoned, which indicates that mixing is not responsible. Another explanation is that the microphenocrysts have been crystallized from assimilated magma. The sample of Numanokawa 4 contains a few plagioclase xenocrysts, which are derived from tonalitic crust. Assimilation of tonalite would not change $\mathrm{Ni} / \mathrm{Mg}$ ratio of the melt, but significantly increases $\mathrm{Fe} / \mathrm{Mg}$ ratio, resulting in crystallization of Fo-poor, Ni-rich olivine.

The above discussion on the NiO-Fo relationships of olivine leads us to the conclusion (Fig. 3) that the parent magmas for the HMVG are of at least two which produced: one produced magmas of rock type $\mathrm{A}$ with lower $\mathrm{Ni} / \mathrm{Mg}$ and $\mathrm{Fe} / \mathrm{Mg}$ ratios than the other, rock type B magmas. The most forsteritic olivine in type $C$ samples has a similar composition to that in type B samples, which indicates that both type B and $\mathrm{C}$ samples have crystallized from magmas with similar $\mathrm{Ni} / \mathrm{Mg}$ and $\mathrm{Fe} / \mathrm{Mg}$ ratios. The difference in olivine compositions of type $\mathrm{B}$ and $\mathrm{C}$ samples resulted from fractional or equilibrium crystallization from similar magmas. The magmas of rock type $A B$ samples are produced through mixing of magmas which yielded rock type $\mathrm{A}$ and $\mathrm{B}$. 


\subsection{Coexisting spinel and olivine compositions}

Compositions of spinel inclusions in olivine phenocrysts and microphenocrysts are plotted in terms of $\mathrm{Cr}, \mathrm{Al}$, and $\mathrm{Fe}^{3+}$ ratios (Fig. 4). Most of them are picotite with $\mathrm{Y}_{\mathrm{Fe}^{3+}}$ $\left(\mathrm{Fe}^{3+} /\left(\mathrm{Cr}+\mathrm{Al}+\mathrm{Fe}^{3+}\right)\right)$ of $0.1-0.4$. More differentiated varieties are titanomagnetite with $\mathrm{TiO}_{2}$ up to $15 \mathrm{wt} \%$. The $Y_{\mathrm{Cr}}\left(\mathrm{Cr} /\left(\mathrm{Cr}+\mathrm{Al}+\mathrm{Fe}^{3+}\right)\right)$ ranges from $0.2-0.5$ for picotite, which is within the range of island arc tholeiitic lavas (Shuto et al., 1985), alkaline basalts (Nagao et al., 1980), mid-oceanic basalts and abyssal peridotites (Dick and Bullen, 1984), whereas, the $Y_{\mathrm{Fe}^{3+}}$ is higher than spinels from any other tectonic situations. These spinels with high $Y_{\mathrm{Fe}^{3}}$ are similar to those found in some alkalic basalts, especially those from the Misasa Formation, southwest Japan (Nagao et al., 1980). $\mathrm{TiO}_{2}$ vs. $\mathrm{Cr} \#$ or $Y_{\mathrm{Fe}^{3}}+$ variations are also close to those of the Misasa basalts.

In Fig. $5,100 \times \mathrm{Cr} /(\mathrm{Cr}+\mathrm{Al})$ ratio $(\mathrm{Cr} \#)$ of spinel inclusions are plotted against $\mathrm{Fo}$ content of the host olivine phenocrysts (microphenocrysts). The coexisting spinel and olivine of the HMVG are greatly dispersed on the Cr\#-Fo diagram, ranging in Cr\# from 20 to 70 and in Fo from 64 to 86 . All these points are plotted to the less forsteritic side of the olivine-spinel mantle array (OSMA) of Arai (1987), indicating that the host rocks do not represent primary magmas. Although the $\mathrm{Cr} \#$ of spinel and the Fo content of the coexisting olivine are not correlated as a whole, the Cr\#-Fo plots for an individual sample displays some systematic correlations. Generally spinels in type A samples do not change $\mathrm{Cr} \#$ with decreasing Fo content of the coexisting olivines. Spinels in type $\mathrm{C}$ samples increase in $\mathrm{Cr} \#$ as Fo content decreases. Spinels in type B and type AB

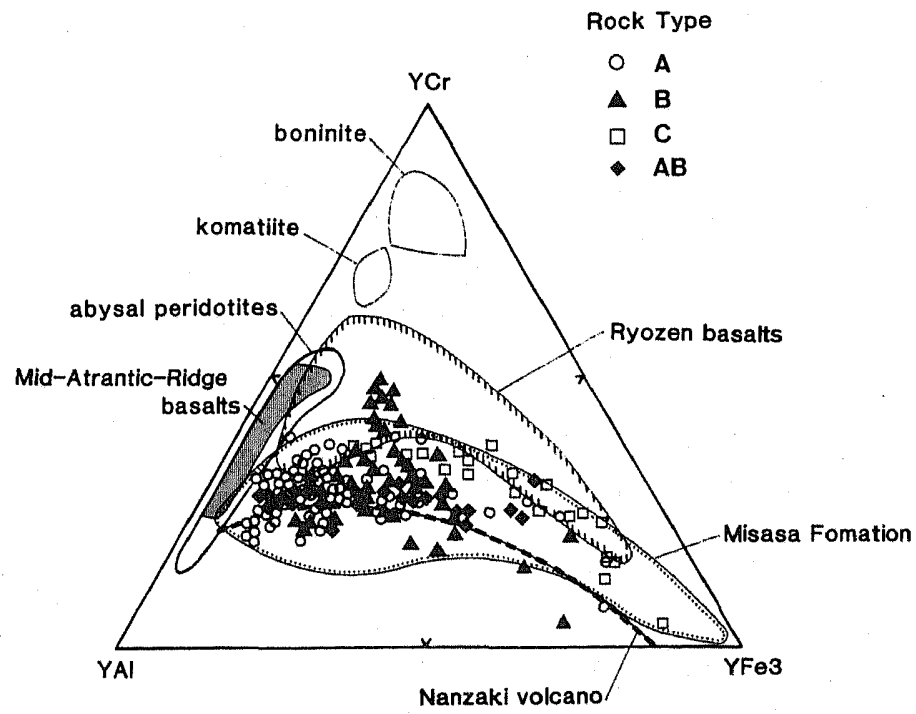

Fig. 4. Spinel compositions plotted in terms of $\mathrm{Cr}-\mathrm{Al}-\mathrm{Fe}^{3+}$ ratio. Also plotted are regions of spinels in abyssal peridotites and mid-A tlantic ridge basalts (Dick and Bullen, 1984), Ryozen basalts and komatiite (Shuto et al., 1985), basalts from the Misasa Formation (Nagao et al., 1980), Nanzaki Volcano (Shiraki et al., 1979), and boninite (Umino, 1986). 
Type A

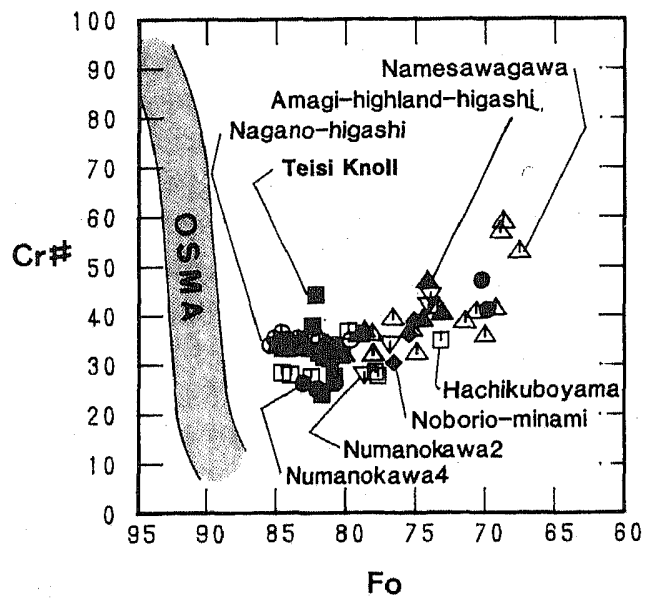

Type $A B$

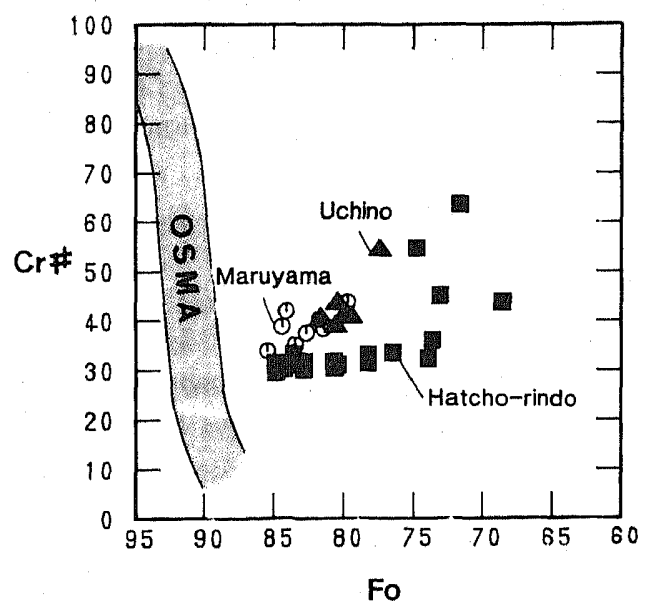

Type $B$

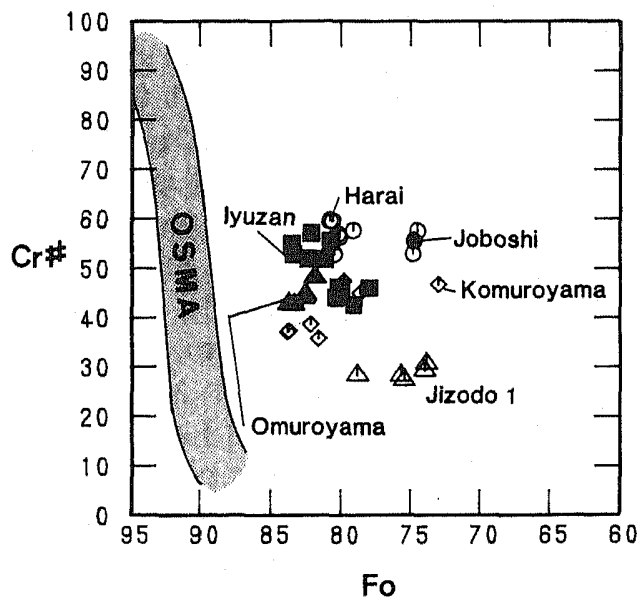

Type C

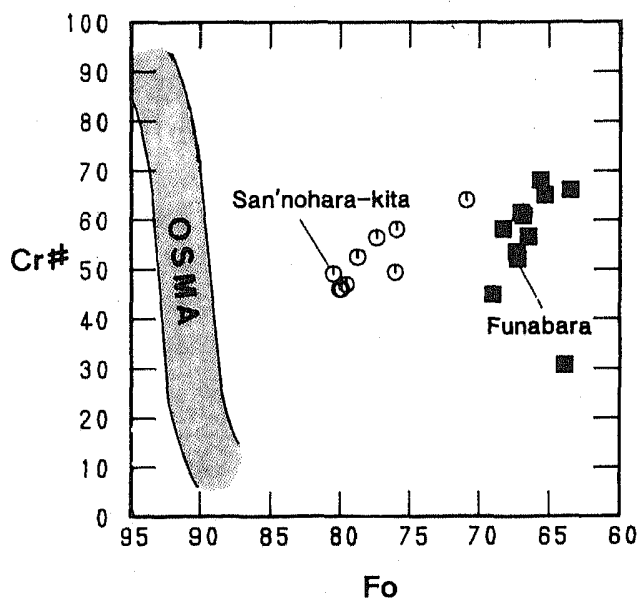

Fig. 5. Cr\# of spinel vs. Fo content of coexisting olivine. OSMA is the olivine-spinel mantle array of Arai (1987).

samples are rather variable. Spinels in the samples of Omuroyama, Komuroyama (type B), Maruyama and Uchino (type AB) trend upper right, while those from Iyuzan trend lower right. Spinels of Joboshi, Jizodo, and Hatcyo-rindo appear to be constant in Cr\#. Such correlations are commonly observed in the coexisting spinel and olivine of various volcanic rocks and cumulates, and are considered to be fractional crystallization paths (Arai and Takahashi, 1987; Arai, 1990). There is a marked correlation between the Cr\# of spinel and the types of the host rocks estimated from the NiO-Fo relationships of olivine. Spinel in type A samples is lower in Cr\# than spinel in type B or C samples at a given Fo content of the coexisting olivine. 
The Cr\# of spinel is considered to be correlated with the degree of partial melting of the host magma (Arai, 1987, 1990). As melting of the mantle peridotite proceeds, both Cr\# of spinel and Fo content of olivine in the residue increase. However, the increase in $\mathrm{Cr}$ \# of spinel is much larger than that in Fo content of olivine. Thus, the $\mathrm{Cr} \#$ of spinel in the residual peridotite is a sensitive indicator of the degree of melting. If two fractionation trends exhibit almost constant CrHs on the CrH-Fo diagram, the difference in the $\mathrm{Cr} \# \mathrm{~s}$ of these two would be correlated with the difference in the degree of partial melting between these two magmas. The Cr\# of spinel crystallized from a segregated magma does not change significantly when that of residual spinel is approximately $0.5 \pm 0.1$. However, if the residual spinel has lower $\mathrm{Cr} \# \mathrm{~s}(<0.5)$, spinel crystallizing from the segregated magmas tends to increase in $\mathrm{Cr} \#$ with decreasing Fo content of co-crystallizing olivine, and the fractionation trends may cross each other at lower Fo contents of coexisting olivine (Arai, 1990). Therefore, direct comparison of the $\mathrm{Cr} \#$ and Fo relations of volcanic rocks is invalid when they are plotted far apart from the OSMA. To exclude these variations in degree of fractionation, Arai (1990) compared the Cr\#s at the points where the extrapolated fractionation trends cross the OSMA. Figure 6 shows some fractionation trends of the HMVG extrapolated to the OSMA. Extensions of the trends of some type B samples cross the OSMA at higher $\mathrm{Cr}$, but other extensions of those of type $\mathrm{A}, \mathrm{B}$, and $\mathrm{C}$ samples are overlapped one another, concentrated in $\mathrm{Cr} \#$ of 0.2-0.35. If parent magmas for these HMVG volcanic rocks were derived from the OSMA as proposed by Arai (1987), their residue would be lherzolite except for Iyuzan, Harai, and Joboshi. This is consistent with the results of melting experiments on an estimated primary magma for the HMVG that it could coexist with upper mantle lherzolite (Tatsumi et al., 1982). However, there is a suspicion for the validity of extrapolating the crystallization trends to the OSMA, because most of the HMVG samples are plotted in a region far less magnesian than the OSMA. Considering the uncertainty of the extrapolation, no significant variations are recognized in the degree of partial melting among the HMVG magmas. Furthermore, the Cr\# of spinel depends on pressure to some degree (Jaques and Green, 1980; Dick and Bullen, 1984), or on the melt compositions (Irvine, 1976). Higher Cr\# of spinel is preferable for crystallization from magmas with higher degrees of partial melting, or crystallization under lower pressures (Dick and Bullen, 1984). However, pressure effect could not explain the coexistence of high- $\mathrm{Cr}$ spinel and high-Ni olivine in type B samples. Experimental studies have detected no significant pressure dependence on the olivine/liquid partition coefficient at least in dry basalt melt up to $16 \mathrm{~kb}$ (Takahashi, 1980). The systematic correlation between the coexisting spinel and olivine compositions is not explicable by the variations in crystallization pressure.

\section{Areal Distribution and Temporal Change of Rock Types}

Figure 7(a) shows location of vents of the HMVG in the eastern Izu Peninsula. The analyzed samples are marked on their vent positions with symbols according to the rock types. Distribution of the vents of rock type $\mathrm{A}$ is concentrated in the southwest of the volcanic region, but Teisi Knoll in the northeastern end is also type A. Type $B$ vents are mainly distributed in Sakibara area, the northeast of the region. Vents of

Vol. 39, No. 1, 1991 

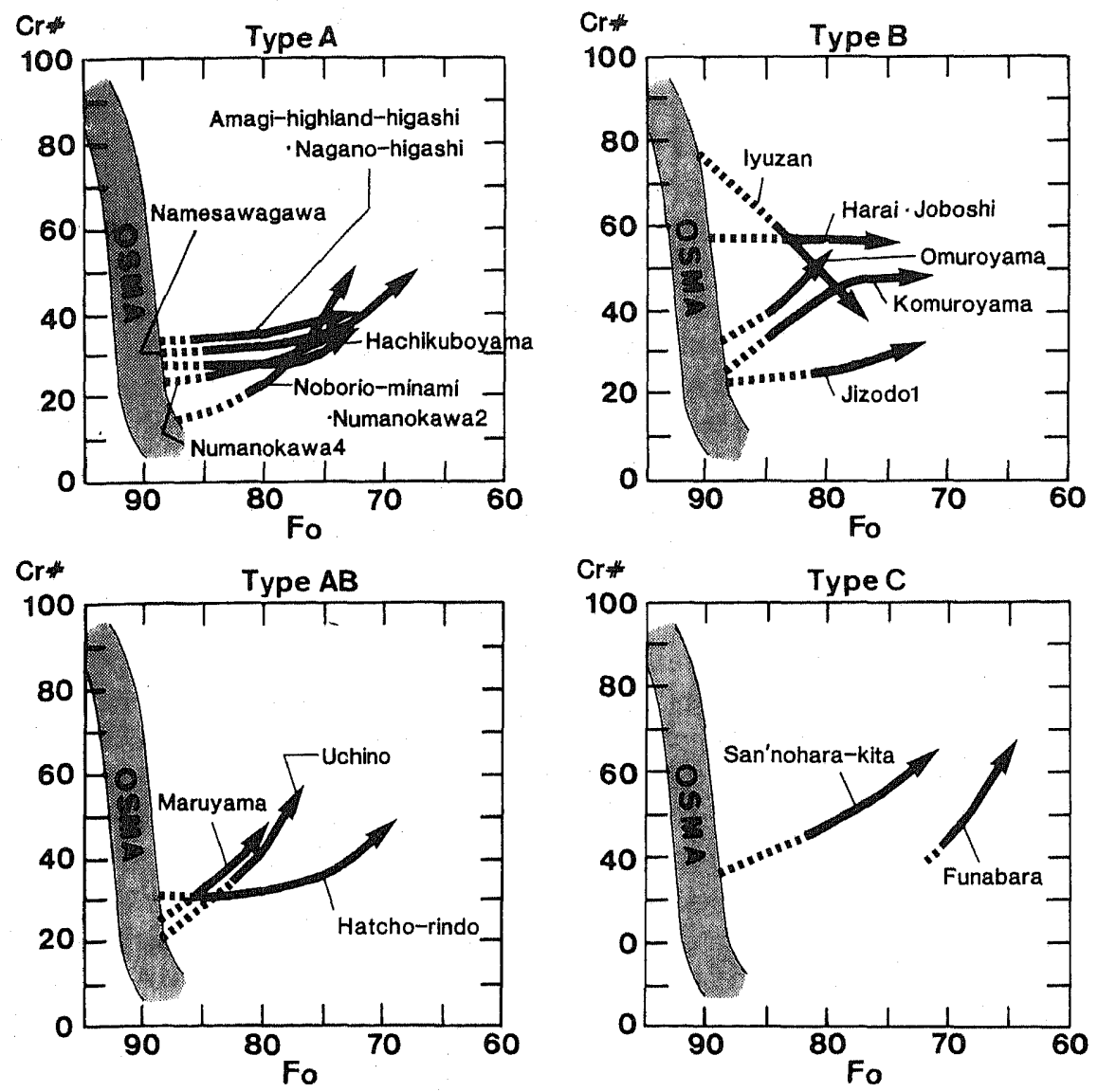

Fig. 6. Fractionation trends in $\mathrm{Cr} \#$ vs. Fo variation diagrams for each rock sample from the HMVG. Type B samples do not change Cr\# with decreasing Fo content, whilst type A samples are highly variable. Extrapolation of these fractionation trends toward the OSMA suggests that residue of these volcanic rocks is lherzolite except Iyuzan and Harai.

rock type $\mathrm{AB}$ tend to be located between the areas underlain by the vents of type $\mathrm{A}$ and $B$. Type $C$ vents appear to lie in the suburbs of the volcanic region in the Izu Peninsula, but if we include all submarine vents, San'nohara-kita is located in the central area of the whole volcanic region. A broken line in Fig. 7(a) encloses area where andesitic $\left(\mathrm{SiO}_{2}>53 \mathrm{wt} \%\right)$ volcanoes are distributed. It should be noted that there is a close resemblance of the distribution of rock type $B$ to that of andesite, suggesting intimate correlation between the olivine and whole rock compositions.

Figure 7(b) shows distribution of the average of $\mathrm{Cr}$ \# of spinel. As the distribution of rock type B, volcanoes with high-Cr spinel are concentrated in Sakibara area. Low-Cr spinel occurs in the southwest, where type A vents are located. However, two volcanoes with very low-Cr spinel are present in the center of the region. One of the type $\mathrm{C}$ vents, 


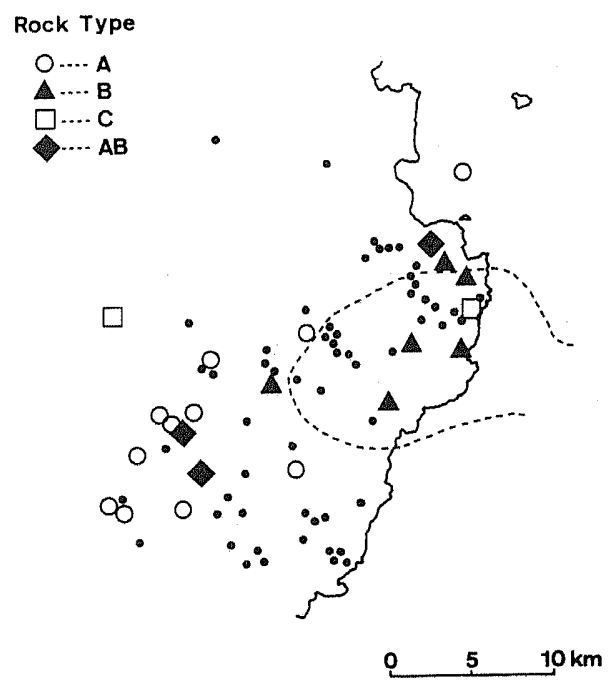

(a)

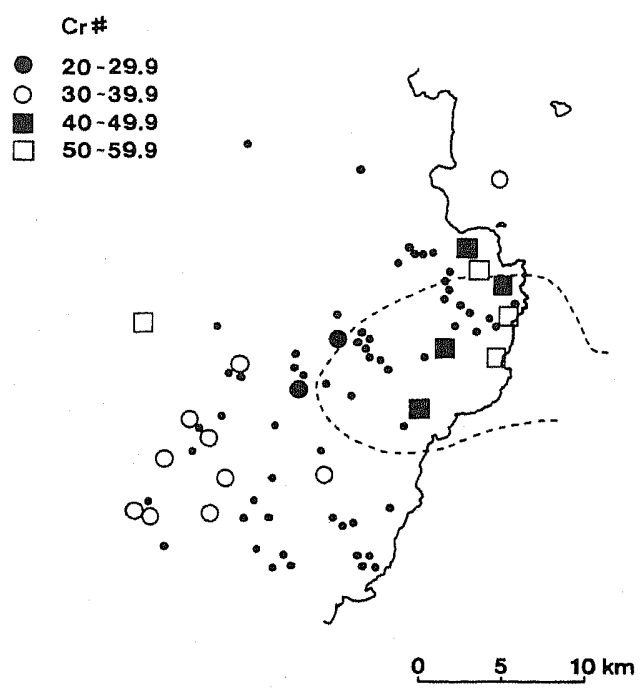

(b)

Fig. 7. (a) Distribution of rock types in the HMVG. A broken line encircles the area where the volcanic ejecta is andesitic $\left(\mathrm{SiO}_{2}>53 \mathrm{wt} \%\right)$. Type $\mathrm{B}$ is concentrated in the northeast, whereas type A occurs in the southwest of the volcanic region. (b) Map showing the average $\mathrm{Cr} \#$ of spinel. As for high-Ni olivine, samples with chromiferous spinel occur in the northeast of the volcanic region. The broken line is the same as that in (a).

Funabara, lies to the northwestern margin of the volcanic region, but yields spinel with high $\mathrm{CrH}$. Again, the coincidence of the distribution of high-Cr spinel with that of andesite is noted.

Temporal variations of the rock types are not systematic in contrast to the regional distribution. Type B occurs in Sakibara area throughout almost the whole length of the volcanic history of the HMVG. On the other hand, activity of type A is not older than 22,000 years B.P. (Koyama et al., 1990). The occurrence of andesite is confined to the northeastern area, suggesting that the assimilation of the upper crust is promoted by the repeated uprise of magmas during the longer periods.

The areal distribution of rock types based on the NiO-Fo relationships of olivine and the $\mathrm{Cr} \#$ of spinel has a close similarity to that of andesite, suggesting that the variations in olivine and spinel chemistry may reflect some regional factors; e.g., regional stress field, composition and thickness of the crust, and mantle heterogeneity. Similar spatial variations have already been recognized for $\mathrm{SiO}_{2}$ content, modal abundance of xenocrysts, and the assemblages of the phenocrysts and the groundmass minerals of the volcanic rocks. Hamuro (1985) has attributed these features to the contamination by the granitic upper crust. Miyajima et al. (1985) stressed the concentric zonal distribution of $\mathrm{SiO}_{2}$ content, and proposed the existence of a zoned magma chamber and concentrically distributed cone sheets. Their grounds are: crustal uplift around Hiekawa, $7 \mathrm{~km}$ west of Ito; positive Bouguer anomaly; distribution of epicenters of 


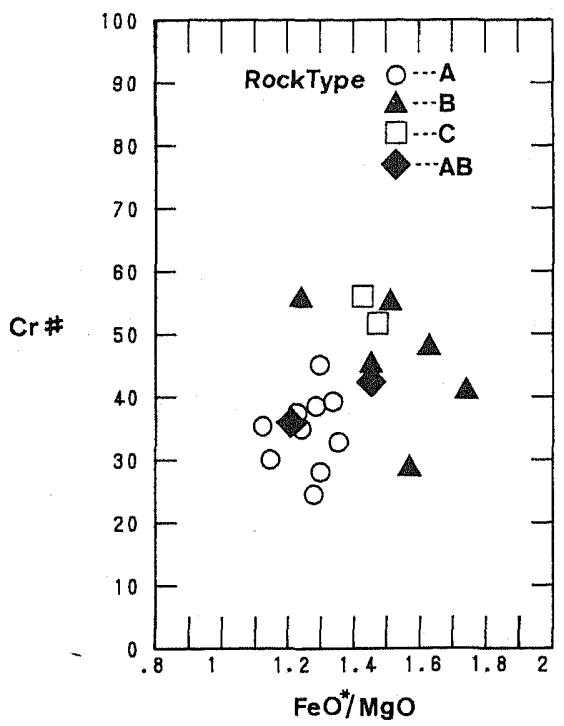

Fig. 8. Correlation between the $\mathrm{Cr} \#$ of spinel and the $\mathrm{FeO} / \mathrm{MgO}$ ratio of the host rocks. Samples of rock type $\mathrm{A}$ are higher in both $\mathrm{Cr} \#$ and $\mathrm{FeO} * / \mathrm{MgO}$ than those of type $B$.

earthquakes; active faults and lineaments suggestive of cone sheets. The first two phenomena, occurring in relatively shallow levels of the crust, may be related to the shallow magma chamber. The existence of the magma chamber is preferable for storing the great volume of magmas ejected from Omuroyama and Kawagodaira, amounting to $0.63 \mathrm{~km}^{3}$, one fourth of the total volume of the HMVG. However, the activity of such large volcanoes is younger than 3,500 years B.P. (Koyama et al., 1990), and any other older volcanoes have not effused larger than $0.3 \mathrm{~km}^{3}$. There is no reason to assume that the magma chamber has existed since the early stages of the HMVG activity. Intrusion of cone sheets would require the existence of the magma chamber as a source of stresses. Vent alignment 2 of Hamuro (1978) may reflect the submerged cone sheet as proposed by Miyajima et al. (1985). Paleomagnetic directions and stratigraphic relationships of the erupted materials suggest linear arrangements of the vents trending NW-SE, which is consistent with the direction of the maximum compressive stress field around the Izu Peninsula (Koyama and Umino, 1991). This fact indicates that the direction of magmatic intrusion is not controlled by a local stress field around the magma chamber but is determined according to the regional stress field. The existence of the vent alignment 2 of Hamuro (1978) is quite doubtful. Consequently, the regional characteristics mentioned above are not ascribable to the magma chamber which might have survived through the whole volcanic activity of the HMVG.

The previous discussion has assumed that olivine and spinel have crystallized from the magmas at considerable depth, at least prior to the crustal contamination at the shallow levels of the crust, because both of them are the first liquidus phases of most basaltic melts. This assumption may be, however, inappropriate, considering the spatial 
distribution and the close correlation of olivine, spinel and the whole rock compositions. Type $\mathrm{B}$ magmas crystallize $\mathrm{Ni}$-rich olivine and $\mathrm{Cr}$-rich spinel, in other words, the olivine crystallizing from type B magmas is fayalitic compared to that from type A magmas with similar $\mathrm{NiO}$ content. This is well presented in Fig. 8, showing the correlation between the average $\mathrm{Cr}$ \# of spinel and the bulk $\mathrm{Fe} / \mathrm{Mg}$ ratio of the host rocks, and the host rock types. Type B samples are higher in $\mathrm{Fe} / \mathrm{Mg}$ than type A samples, which is in accordance with the presence of less forsteritic olivine in the former. Type B samples are also higher in $\mathrm{SiO}_{2}$, which is, in part, due to contamination by crustal materials (Hamuro, 1985). Miyajima et al. (1985) and Hamuro (1985) described tonalitic xenoliths with $\mathrm{Fe} / \mathrm{Mg}$ ratio of $1.89-5.05$ to be candidates for the contaminant. Assimilation of the tonalitic crust with such high $\mathrm{Fe} / \mathrm{Mg}$ ratios will significantly increase the $\mathrm{Fe} / \mathrm{Mg}$ ratio of the host magma without changing the $\mathrm{Ni} / \mathrm{Mg}$ ratio. If the olivine in type $\mathrm{B}$ samples have crystallized from the assimilated magmas, it would inevitably be enriched in $\mathrm{Fe} / \mathrm{Mg}$ while the $\mathrm{Ni} / \mathrm{Mg}$ ratio of the olivine would be similar to that crystallized from non-assimilated magmas. High-Cr spinels in type B samples is also consistent with crystallization from the assimilated magmas because higher $\mathrm{SiO}_{2}$ content is preferable for higher Cr\#s of spinel. As the site of assimilation is restricted in the shallow levels of the crust, high-Cr spinel in type B magmas is in part due to lower crystallization pressures than type A magmas. It is likely that type A magmas have been cooled during the ascent from the source mantle and crystallized spinel and olivine before reaching the upper tonalitic crust.

\section{Concluding Remarks}

The HMVG volcanic rocks have been differentiated from at least two parent magmas on the basis of the NiO-Fo relationships of olivine and $\mathrm{Cr} \#$ of spinel. The cause of this diversity is due to the crustal assimilation, and probably in part, to the difference in the crystallization pressure. Although the Cr\#-Fo relationships among the HMVG volcanic rocks suggest no significant variations in the degree of partial melting, either the diversity of the degree of partial melting or the heterogeneity of the source mantle is not thoroughly excluded. These possibilities, together with the temporal variations in mineral chemistry, require further consideration.

We are grateful to Prof. T. Fujii who stimulated us during the course of our study and reviewed the manuscript. An earlier version of this manuscript greatly benefited from a review by Dr. H. Iwamori. Dr. K. Hamuro and Prof. S. Aramaki kindly provided us some of the analyzed samples.

\section{REFERENCES}

Arai, S., An estimation of the least depleted spinel peridotite on the basis of olivine-spinel mantle array, N. Jb. Miner. Mh., 8, 347-354, 1987.

Arai, S., The origin of upper mantle peridotite, Science, 60, 103-112, 1990 (in Japanese).

Arai, S. and N. Takahashi, Petrographical notes on deep-seated and related rocks (5). Compositional relationships between olivine and chromian spinel in some volcanic rocks

Vol. 39, No. 1, 1991 
from Iwate and Rishiri volcanos, NE Japanese Arc, Ann. Rep., Inst. Geosci., Univ. Tsukuba, 13, 110-114, 1987.

Aramaki, S. and K. Hamuro, Geology of the Higashi-Izu monogenetic volcano group, Bull. Earthq. Res. Inst., Univ. Tokyo, 52, 235-278, 1977 (in Japanese).

Bence, A.E. and A.L. Albee, Empirical correction factors for the electron microanalysis of silicates and oxides, J. Geol., 76, 382-403, 1968.

Dick, H.J.B. and T. Bullen, Chromian spinel as a petrogenetic indicator in abyssal and alpine-type peridotite and spatially associated lavas, Contrib. Mineral. Petrol., 86, 54-76, 1984.

Hamuro, K., Geology of Omuroyama volcano group, Bull. Geol. Soc. Jpn., 84, 433-444, 1978 (in Japanese).

Hamuro, K., Petrology of the Higashi-Izu monogenetic volcano group, Bull. Earthq. Res. Inst., Univ. Tokyo, 60, 335-400, 1985.

Hamuro, K., S. Aramaki, H. Kagami, and K. Fujioka, The Higashi-Izu-oki submarine volcanoes, Part 1, Bull. Earthq. Res. Inst., Univ. Tokyo, 55, 259-297, 1980 (in Japanese).

Hamuro, K., S. Aramaki, K. Fujioka, T. Ishi, T. Tanaka, and K. Uto, The Higashi-Izu-oki submarine volcanoes, Part 2, and the submarine volcanoes near the Izu Shoto Islands, Bull. Earthq. Res. Inst., Univ. Tokyo, 58, 527-557, 1983 (in Japanese).

Hirano, M., K. Hamuro, and N. Onuma, $\mathrm{Sr} / \mathrm{Ca}-\mathrm{Ba} / \mathrm{Ca}$ systematics in Higashi-Izu monogenetic volcano group, Izu Peninsula, Japan, Geochem. J., 16, 311-320, 1982.

Irvine, T. N., Chromite crystallization in the join $\mathrm{Mg}_{2} \mathrm{SiO}_{4}-\mathrm{CaMgSi}_{2} \mathrm{O}_{6}-\mathrm{CaAl}_{2} \mathrm{Si}_{2} \mathrm{O}_{6}-\mathrm{MgCr}_{2} \mathrm{O}_{4}-$ $\mathrm{SiO}_{2}$, Carnegie Inst. Washington Yearb., 76, 465-472, 1976.

Jaques, A.L. and D.H. Green, Anhydrous melting of peridotite at $0-15 \mathrm{~kb}$ pressure and the genesis of tholeiitic basalts, Contrib. Mineral. Petrol., 73, 287-310, 1980.

Koyama, M. and S. Umino, Why does the Higashi-Izu monogenetic volcano group exist in the Izu Peninsula?: relationships between late Quaternary volcanism and tectonics in the northern tip of the Izu-Bonin arc, J. Phys. Earth, 39, 391-420, 1991.

Koyama, M., S. Umino, and Y. Hayakawa, Model of the Higashi-Izu monogenetic volcano group and late Quaternary tectonics in and around the Izu Peninsula, Programme and Abstracts, the Volcanological Society of Japan, No. 2, 50, 1990 (in Japanese).

Kuno, H., Geology and petrology of Omuro-yama volcano group, north Izu, J. Fac. Sci. Univ. Tokyo, Sec. II, 9, Part II, 481-509, 1954.

Miyajima, H., T. Yoshida, and K. Aoki, Geochemical study of the Higashi-Izu monogenetic volcano group, Rep. Nuclear Res. Inst., 18, 158-174, 1985 (in Japanese).

Nagao, T., M. Yamamoto, and K. Onuma, Crystallization trend of chromian spinel in some alkali basalts and calc-alkali andesites from Japanese Island, J. Jpn. Assoc. Min. Petr. Econ. Geol., 75, 44-54, 1980.

Nakamura, Y. and I. Kushiro, Compositional relations of coexisting orthopyroxene, pigeonite and augite in a tholeiitic andesite from Hakone Volcano, Contrib. Mineral. Petrol., 58, 265-275, 1970.

Roeder, P.L. and R.F. Emslie, Olivine-liquid equilibrium, Contrib. Mineral. Petrol., 29, 275-280, 1970.

Sakuyama, M., Petrological study of the Myoko and Kurohime volcanoes, Japan: crystallization sequence and evidence for magma mixing, J. Petrol., 22, 553-583, 1981.

Shiraki, K., F. Ohashi, and N. Kuroda, Chrome-spinels in a basanitic lava from Nanzaki Volcano, Izu Peninsula, J. Jpn. Assoc. Min. Petr. Econ. Ged., 74, 114-121, 1979 (in Japanese).

Shuto, K., R. Yashima, and T. Takimoto, Primitive olivine tholeiite from the Ryozen district, 
northeastern part of Fukushima Prefecture, northeast Japan, J. Jpn. Assoc. Min. Petr. Econ. Geol., 80, 55-72, 1985.

Takahashi, E., Olivine/liquid nickel partitioning at high pressure: experiments with an olivine capsule, EOS, 61, 397, 1980.

Tatsumi, Y., M. Sakuyama, H. Fukuyama, and I. Kushiro, Origin of are basalt magmas, and its bearing on thermal structure of the upper mantle beneath volcanic arc, Bull. Volcanol. Soc. Jpn., 27, 45-65, 1982 (in Japanese).

Umino, S., Magma mixing in boninite sequence of Chichijima, Bonin Islands, J. Volcanol. Geotherm. Res., 29, 125-158, 1986.

Yuasa, M. and E. Honza, Dredged basalt from the knoll between the Izu Peninsula and Izu-Oshima Island, Bull. Geol. Surv. Jpn., 27, 721-730, 1976. 